\title{
The dynamics of free amino acids in the grains Tripogon chinensis (Franch.) Hack. when germinating in the conditions of the osmotic stress
}

\author{
Irina Plyaskina ${ }^{1, *}$, Evgenii Bondarevich ${ }^{1}$, Igor Boriskin ${ }^{2}$, Natalia Kotsyurzhinskaya $^{1}$ and \\ Ludmila Ishina $^{2}$ \\ ${ }^{1}$ FSBEI HE "Chita State Medical Academy", Chita, 672000, Russia \\ ${ }^{2}$ Transbaikalian Agrarian Institute - branch of FSBEI HE "Irkutsk State Agrarian University named \\ after A.A. Ezhevsky ", Chita, 672023, Russia
}

\begin{abstract}
The content of free amino acids in seeds and sprouts of T. chinensis in the control and at an osmotic pressure of $5 \mathrm{~atm}$. was determined. The group of acidic and basic amino acids predominates in seeds. An adaptive reaction to a physiological drought is the transformation of the free amino acids metabolism. This is expressed in an increase in the total amount of free amino acids at the osmotic pressure of $5 \mathrm{~atm}$., providing the osmotic component of adaptation. Under the conditions of the osmotic stress, the concentration of acidic and basic amino acids increases up to 48 hours, this may be due to the continued hydrolysis of reserve proteins. Under the influence of the osmotic stress there are changes in the group of amino acids, the metabolic precursor of which is glutamic acid. The amino acids, a part of this group, exhibit protective, signaling properties. Thus, the increase in the arginine concentration and ornithine is noted; this indicates the activation of the ornithine cycle and on the increase of amino acids catabolism. The revealed features can ensure the successful germination of $T$. chinensis grains under the conditions of the physiological drought.
\end{abstract}

\section{Introduction}

One of the mechanisms ensuring resistance to the stresses of different nature (cold, drought, hypoxia) is the accumulation of free amino acids [1-4]. All types of influences are reflected at the level of free amino acids. Cold and drought cause an increase in the amount of free amino acids, and hypoxia leads to a decline in their concentration. The glutamic acid and

\footnotetext{
* Corresponding author: thebestdamnthing@mail.ru
} 
substances, for which it is a metabolic predecessor (glutamine, proline, ornithine, arginine, $\gamma$-aminobutyric acid) dominate in stress conditions. From this group, the functions of $\gamma$ aminobutyric acid and proline are most widely discussed as stress metabolites [5]. The intensity of accumulation of alanine, proline, hydroxyproline and glycine in deficit of water can change due to the use of these amino acids on the synthesis of the corresponding betaines, known for its osmoregulation properties [6]. The great part of research works on studying of amino acid composition are related to species of nutritional, fodder or pharmacological value [7,8]. Most often such cereals as wheat, corn, rice, barley, sorghum, triticale are the objects of these researches [9, 10]. The wild cereals are insufficiently studied in this aspect. On the territory of the Eastern Transbaikaliye, the plants of a xeromorphic nature are prevalent; they are resistant to the conditions of habitat with a lack of moisture. One of such kind of plants is Tripogon chinensis (Franch.) Hack. - a relict cereal which is growing on the petrophytic plots of the slopes where it is exposed to extreme environmental factors (temperature fluctuations, insufficient moisture, insolation, etc.). Therefore, the study of the effect of conditions that imitate a physiological drought on the dynamics of free amino acids can contribute to the definition of mechanisms for the adaptation of the wild cereals of the Eastern Transbaikaliye. The aim of the study is to determine the effect of osmotic stress on the dynamics of free amino acids in seeds and sprouts of $T$. chinensis

\section{Materials and Methods}

\subsection{Object of study}

T. chinensis is the only representative of the genus Tripogon in Russia, although this tropical genus noted in Asia and Africa, includes about 30 species, 1 species in America [11]. The species lives in strictly defined biotopes, growing in the petrophytic steppes along stony tops of hills, on the surfaces of rocks and large boulders, often forming a three-beard low-grass steppe [11-13]. This drought-resistant mountain-steppe species of eastern Asia is located in the Eastern Transbaikalye on the northern border of its natural habitat. The habitat of the species covers the southern regions of the Transbaikalian Region, Manchuria, Korea, Mongolia and is mentioned in the Jewish Autonomous Region and in the Khabarovsk Territory.

Only seed reproduction is characterized for the T. chinensis. Therefore, the adaptations that ensure the germination of seeds and the further growth of $T$. chinensis in extreme environmental conditions are of particular interest. The material for the study was mature purified T. chinensis grains harvested in 2014 in the Akshinsky district of the Transbaikalian region and sprouts (24, 48 and 72 hours).

\subsection{Methods}

The germination of seeds was carried out in the dark at $20^{\circ} \mathrm{C}$ during three days. The osmotic stress was created with an aqueous solution of mannit with a concentration of $0.208 \mathrm{~mol} / \mathrm{l}$, which corresponds to an osmotic pressure of $5 \mathrm{~atm}$. Control groups of grains were germinated on filter paper moistened with distilled water, and experienced - in the presence of osmotics, which led to the formation of a physiological drought. Every day the amount of germinating seeds was determined (in \%). For the determination of free aminoacids, weights of cereal grains (dry and germinated) weighing $50 \pm 0.2 \mathrm{mg}$ were used. The extraction of free aminoacids was carried out with a $0.89 \%$ solution of sodium chloride. The water-salt extract was dissolved in acetonitrile (1:1). The content of free 
aminoacids was determined by the method of the high-effective liquid chromatography [14]. The content of 20 aminoacids is determined, 2 of which are non-proteinogenic (taurine and ornithine). The obtained data was subjected to statistical processing with the help of the package Microsoft Excel 2010 and PAST 3.0 [15].

\section{Results and Discussion}

The visible seed germination in the control and at an osmotic pressure of 5 atm. was observed on the second day, but under the osmotic stress conditions the germination rate was lower (71.1 and $45.1 \%$ accordingly). On the third day the germination rate in all samples was $89 \%$. The dynamics of free amino acids was studied, See Table 1.

Table 1. Dynamics of free amino acids (in $\mu \mathrm{g} / \mathrm{g}$ in wet mass) in seeds and sprouts of $T$. chinensis under the conditions of the osmotic stress

\begin{tabular}{|c|c|c|c|c|c|c|c|}
\hline \multirow{2}{*}{$\begin{array}{c}\text { Amino } \\
\text { acids }\end{array}$} & \multirow{2}{*}{$\begin{array}{c}\text { Dry } \\
\text { seeds }\end{array}$} & \multicolumn{3}{|c|}{ Control } & \multicolumn{3}{c|}{5 atm. } \\
\cline { 3 - 8 } & & $24 \mathrm{~h}$ & $48 \mathrm{~h}$ & $72 \mathrm{~h}$ & $24 \mathrm{~h}$ & $48 \mathrm{~h}$ & $72 \mathrm{~h}$ \\
\hline Asp & 13,9 & 62,15 & 25,38 & 300,94 & 62,74 & 261,77 & 140,86 \\
\hline Glu & 47,2 & 216,76 & 88,52 & 625,62 & 213,22 & 933,31 & 443,47 \\
\hline Asn & 51,51 & 180,9 & 73,87 & 1252,42 & 232,77 & 601,44 & 343,95 \\
\hline Gln & 88,78 & 499,84 & 204,12 & 2385,08 & 401,21 & 537,67 & 1243,13 \\
\hline Ser & 9,38 & 229,27 & 93,63 & 290,73 & 42,4 & 787,5 & 125,77 \\
\hline Gly & 33,03 & 187,97 & 76,76 & 612,94 & 149,28 & 714,37 & 257,4 \\
\hline Thr & 52,39 & 64,79 & 26,46 & 99,78 & 236,76 & 183,68 & 49,04 \\
\hline Ala & 5,37 & 230,03 & 93,94 & 135,14 & 24,25 & 845,54 & 5,9 \\
\hline His & 285,04 & 94,45 & 38,57 & 286,19 & 499,18 & 377,32 & 144,76 \\
\hline Lys & 31 & 38,67 & 15,79 & 68,91 & 140,08 & 171,47 & 25,67 \\
\hline Arg & 11,49 & 50,03 & 20,43 & 36.14 & 51,93 & 187,1 & 20,95 \\
\hline Trp & 12,6 & 48,16 & 19,67 & 150,39 & 56,94 & 182,89 & 41,56 \\
\hline Phe & 32,34 & 66,95 & 27,34 & 229,05 & 146,14 & 168,89 & 109,09 \\
\hline Tyr & 16,52 & 94,43 & 38,56 & 104,74 & 74,63 & 229,16 & 40,68 \\
\hline Met & 8,14 & 21,82 & 8,91 & 74,36 & 36,77 & 31,95 & 23,74 \\
\hline Val & 26,64 & 144,04 & 58,82 & 188,01 & 115,86 & 430,86 & 70,11 \\
\hline Ile & 18,35 & 64,26 & 26,24 & 129,01 & 82,93 & 236,35 & 54,28 \\
\hline Leu & 14,54 & 125,98 & 51,45 & 157,48 & 65,73 & 412,56 & 74,16 \\
\hline Taurine & 7,72 & 139,54 & 56,99 & 21,31 & 34,89 & 1088,4 & 32,07 \\
\hline Ornithine & 6,64 & 23,27 & 9,5 & 11,76 & 30,02 & 54,45 & 37,79 \\
\hline $\begin{array}{c}\text { Amount of } \\
\text { free amino } \\
\text { acids }\end{array}$ & 772,58 & 2583,31 & 1054,95 & 7123,86 & 2697,73 & 8436,68 & 3284,38 \\
\hline & & & & & & & \\
\hline & & & & & & \\
\hline
\end{tabular}


In the dry grains of $T$. chinensis the group of acidic and basic amino acids predominates, what is characteristic as well of seeds of grain cereals [3, 16]. Especially the histidine content is great $(285.04 \mu \mathrm{g} / \mathrm{g}$ in wet mass). According to the dynamics of the number of acidic amino acids and their amides the following features were noted. In comparison with dry grains in the first 24 hours from the onset of the germination the concentration of Asp and Glu was increased more than in 4 times, and of amides - more than in 5 times. The similar results were observed under conditions with an osmotic pressure of $5 \mathrm{~atm}$. At 48 hours from the onset of germination in the control the number of all the amino acids in the group decreased and increased again to 72 hours. The contents of Gln and Asn, the main donors of the amino groups, had the maximum values. Under conditions of osmotic stress the maximum for Glu was noted at the time of 48 hours, and the maximum for Gln after 72 hours.

On the first day there was an increase in the number of Ser and Gly, to the second day in the control - a significant portion of these amino acids are consumed, and after 72 hours their concentration increases again. Whereas under the conditions of osmotic stress the amount of Ser and Gly continued to increase up to 48 hours, reaching the maximum values (787.5 and $714.37 \mu \mathrm{g} / \mathrm{g}$ in wet mass) and the decrease occurred at 72 hours. A similar trend is noted for Ala. The concentration of threonine in the control in comparison with dry grains changed insignificantly, whereas under stress conditions the increase in its content was significantly greater. The main amino acids were characterized by the following dynamics features. In control the consumption of His lasts during the first day and under the osmotic stress the concentration of this amino acid increases almost in 2 times. Also, osmotic stress leads to an increase in the concentration of Lys and Arg up to $48 \mathrm{~h}$, but then their concentrations were sharply decreased. A number of researches approves increase of quantity of arginine in a drought $[17,18]$. At 5 atm. on second day concentration of arginine was maximal $(187,1 \mu \mathrm{g} / \mathrm{g}$ in wet mass), further concentration decreases, that coincides with activization of growth processes. Amino acids of ornithine cycle (arginine, ornithine, citrulline) accumulate the amine nitrogen which is released hydrolysis of proteins in stress conditions, are metabolic predecessors of polyamines performing protective functions [19]. It can be assumed that the osmotic stress is carried more successful by this type of cereals in connection with the dynamics of ornithine. This metabolite reflects the level of the pathway work for free ammonia binding.

The aromatic and hydrophobic neutral amino acids are emitted in the first days as a result of a proteolysis of the reserve proteins and this process at 5 atm. occurs up to $48 \mathrm{~h}$. This can explain a large amount of the free amino acids at $5 \mathrm{~atm} .(8436,68 \mathrm{in} \mu \mathrm{g} / \mathrm{g}$ in wet mass).

Thus, the osmotic stress leads to a slowdown of the water flow into the seed, this is reflected on the processes that ensure the transition to the start-up of growth. The study of the dynamics of free amino acids in $T$. chinensis showed that during the swelling process an increase in the concentration of all amino acids (except His) occurs due to the hydrolysis of reserve proteins. The growth processes, actively coming from the second day, lead to the involvement of amino acids in the synthesis of metabolites, this is accompanied by a drop in the concentration of amino acids.

\section{References}

1. O.I. Yakhin, A.A. Lubyanov, Z.F. Kalimullina, R.A. Batraev, Izvestia Orenburg state agrarian univ. 33, 38-40 (2012)

2. N.E. Sudachkova, I.L. Milyutina, L.I. Romanova Free, J. Stress Physiol. 3, 4-14 (2007)

3. S. Movafegh, R. Jadid, S. Kiabi, Jour. of Stress Phys. Biochem. 8, 157-168 (2012) 
4. E.V. Alaudinova, P.V. Mironov, Khimija Rastitel'nogo Syr'ja 3, 85-91 (2017)

5. A.W. Bown, B.J. Shelp, Plant Phys. 115, 1-5 (1997)

6. A.D. Hadson, B. Rathinasabapathi, J. Rivoal, M. Burnet, M.O. Dillon, D.A. Gage, Plant Biol. 91, 306-310 (1994)

7. B. Pisarikova, S. Kracmar, I. Herzig, Czech J. Anim. Sci. 50, 169-174 (2005)

8. J.H. Umrani, V.M. Pahoja, I.T. Ansari, M.A. Sahito, B.U. Panhwar, S.P. Tunio, Journ. of Agriculture and Veterinary Scien. 2, 18-20 (2013)

9. A.C. Stringfellow, J.S. Wall, G.L. Donaldson, R.A., Cereal Chem. 53, 51-60 (1975)

10. J. Mosse, J.C. Huet, J. Baudet, Cereal Chem. 65, 271-277 (1988)

11. N.N. Tzvelev, The cereals of USSA (Nauka, Leningrad, 1976)

12. M.N. Lomonosova, Flora of Siberia. Vol. 2. Poaceae (Gramineae) (Nauka, Novosibirsk, 1990)

13. N.S. Probatova, The Red Book of Russian Federation (plants and mushrooms) (KMK Scientific Press Ltd., Moscow, 2008)

14. T. Teerlink, Clinical Chem. 42, 245-249 (1994)

15. Ø. Hammer, D.A.T. Harpe, P.D. Ryan, Palaeontologia Electronica 4, 1-9 (2001)

16. P.E. Padgett, R.T. Leonard, Journ. of Exp. Botany 47, 871-883 (1996)

17. S. Kawasaki, C. Miyake, T. Kouchi, A. Yokota, Plant Cell Phys. 41, 864-873 (2000)

18. P. Diaz, O. Borsani, A. Marquez, J. Monza, Lotus Newsletter 356, 83-92 (2005)

19. J.H. Liu, H. Kitashiba, J. Wang, Y. Ban, T. Moriguchi, Plant Biotechnol. 24, 117-126 (2007) 